\title{
Pinus nigra Arn. ssp. salzmannii seedling recruitment is affected by stand basal area, shrub cover and climate interactions
}

\author{
Manuel E. Lucas-Borja ${ }^{1}$ • David Candel-Pérez ${ }^{1}$ - Francisco A. García Morote ${ }^{1}$. \\ Thierry Onkelinx ${ }^{2} \cdot$ Pedro A. Tíscar ${ }^{3} \cdot$ Philippe Balandier $^{4}$
}

Received: 22 July 2015 / Accepted: 21 March 2016/Published online: 1 April 2016

(C) INRA and Springer-Verlag France 2016

\begin{abstract}
- Key message Shrub cover has visible effects on Pinus nigra Arn ssp. salzmannii seedling emergence, but only in drier years under moderate basal area (25$30 \mathrm{~m}^{2} \mathrm{ha}^{-1}$ ). In the wetter year, shrub cover favours seedling survival without basal area influence.

- Context Shrubs are known to favour tree seedling recruitment in difficult climate environments, but facilitation may prove optimal in intermediate-level rather than harsh conditions, although such an effect remains to be specified.

- Aims The main aim of this work was to evaluate the influence of stand basal area $(15-20,25-30$ and $35-$ $\left.40 \mathrm{~m}^{2} \mathrm{ha}^{-1}\right) \times$ with/without shrub facilitation on seedling recruitment in Spanish black pine (P. nigra Arn. ssp. salzmannii), which has been struggling to regenerate natural
\end{abstract}

Handling Editor: Laurent Bergès

Contribution of the co-authors ME Lucas-Borja and D Candel-Pérez conceived the research, obtained the field data, run the data analysis and wrote the manuscript. PA Tíscar, T Onkelinx and P Balandier run the data analysis and wrote the manuscript. FA García Morote obtained the field data and wrote the manuscript.

Manuel E. Lucas-Borja

manuelesteban.lucas@uclm.es

David Candel-Pérez

David.CandelPerez@uclm.es

Francisco A. García Morote

FcoAntonio.Garcia@uclm.es

Thierry Onkelinx

Thierry.Onkelinx@inbo.be

Pedro A. Tíscar

pedroa.tiscar@juntadeandalucia.es forests since the late nineteenth century, sometimes jeopardizing stand persistence.

- Methods In spring 2012 and 2013, 72 subplots of $25 \times 25 \mathrm{~cm}$ were established in Cuenca Mountains, centraleastern Spain (four replicates, each counting three subplots $\times 2$ shrub conditions, both under and outside shrub cover, in three different stand basal areas). All plots were randomly distributed at least $500 \mathrm{~m}$ apart within each stand basal area. Each subplot comprised 20 seeds previously collected at the experimental forest site. Seedling emergence and early survival were monitored every month in 2012 and 2013.

- Results Seedling recruitment was strongly influenced by year. The year 2012 was drier and warmer than 2013. In 2012, seedling emergence was higher under the 25-30$\mathrm{m}^{2} \mathrm{ha}^{-1}$ stand basal area and favoured by shrub cover, whereas in 2013, neither basal area nor shrub cover had significant effects. No seedling survived the summer in 2012. Higher seedling survival was found outside shrub cover at every basal area interval in 2013 with living seedlings until the end of the year.

Philippe Balandier

philippe.balandier@irstea.fr

Departamento de Ciencia y Tecnología Agroforestal y Genética, Universidad de Castilla-La Mancha, Campus Universitario s/no., 02071 Albacete, Spain

2 INBO, Research Institute for Nature and Forest, Kliniekstraat 25, 1070 Brussels, Belgium

3 Centro de Capacitación y Experimentación Forestal, C/. Vadillo-Castril s/no., 23470 Cazorla, Spain

4 Irstea, UR EFNO, Nogent-sur-Vernisson F-45290, France 
- Conclusion Climate is the main factor controlling seedling emergence and survival. Shrub facilitation has visible effects on seedling emergence, but only in drier years under moderate light (moderate basal area). Facilitation collapses at extreme stress levels. In wetter years, shrub cover does not promote seedling survival and basal area is not an influential factor.

Keywords Tree regeneration $\cdot$ Nurse plants $\cdot$ Climate change $\cdot$ Resource limitation $\cdot$ Light $\cdot$ Water $\cdot$ Plant interactions $\cdot$ Facilitation

\section{Introduction}

Under the Convention for the Conservation of European Wildlife and Natural Habitats (Resolution 4/1996), EU directives classified Spanish black pine forests as 'habitats of European interest' requiring specific conservation measures, partly due to the lack of basic understanding on the regeneration biology of this long-lived species (Kerr 2000, 2008). Several authors have cited a number of big problems for successful natural regeneration of Spanish black pine: irregular masting conditions, dry summers over a period of at least 3 years, excessive grazing and uncontrolled ploughing (Del Cerro et al. 2009; Lucas-Borja et al. 2010, 2011, 2012; Tíscar and Linares 2014). Moreover, forecasts suggest these pine forests will be soon one of the forest ecosystems hit hard by climate change, and their current distribution could shrink dramatically (López Serrano et al. 2009). In this context, nurse shrubs and adequate overstory density may facilitate seedling germination, emergence and survival in harsh environments. However, the issue of how combinations of tree canopy and shrub covers affect initial Spanish black pine seedling recruitment has never been investigated.

Plant-plant interactions range from negative (e.g. competition or allelopathy) to positive relationships (e.g. facilitation). Numerous studies consistently demonstrated that shrubs can act as nurse plants favouring plant seedling establishment through facilitative interactions with beneficiary plants in extreme environments worldwide (e.g. Kitzberger et al. 2000; Gómez-Aparicio et al. 2005; Howard et al. 2012). Shrubs are also recognized as important niches for tree regeneration (Callaway 1995; Rodríguez-García et al. 2011). The positive impact of one plant on another has been shown to occur by offering shading that helps improve microclimate (evapotranspiration lessening), increase nutrient availability and increase soil stability (see Callaway 1995 for a review). However, facilitation, competition and the direction of plant-plant interactions frequently change in response to environmental conditions (Kitzberger et al. 2000; Callaway et al. 2002; Maestre and Cortina 2004; Le Bagousse-Pinguet et al. 2014). Callaway and Walker (1997) pointed out that the importance of facilitation and competition varies inversely across a gradient of abiotic stress, with facilitation dominating under highly stressful conditions. Sthultz et al. (2007) showed that Pinus edulis Engelm. and Fallugia paradoxa D. Don (a common shrub in the semiarid south-western USA) interactions shifted from facilitation at high-stress to competition at low-stress sites, which is consistent with the stress gradient hypothesis (SGH) posed by Bertness and Callaway (1994). Conversely, Maestre et al. (2005) found that neither positive nor negative plant-plant interactions increased with increasing abiotic stress in arid and semiarid environments. Furthermore, different studies found that facilitation often collapses at the extreme end of stress and physical disturbance gradients, due to a decrease or disappearance of the effect of the nurse plant species (e.g. Michalet et al. 2006, 2014).

The study of shrub and tree canopy cover interactions may help us to understand the population dynamics involved as a step towards guaranteeing forest persistence. According to different studies, the presence and abundance of tree canopy cover affect natural regeneration success during the early phase of the regeneration cycle (Emborg 1998; Page et al. 2001). Changing shelterwood density has a strong influence on understorey light and soil moisture, which may affect seedling performance and thus ultimately regeneration outcome (Agestam et al. 2003; Balandier et al. 2006a). Recent studies in Mediterranean ecosystems investigated influences of canopy cover on the natural regeneration mechanisms of its main species, including Pinus sylvestris L. (Barbeito et al. 2009), Pinus nigra Arn. (Del Cerro et al. 2009; Tíscar 2007; LucasBorja et al. 2011), Pinus pinea L. (Adili et al. 2009), Pinus halepensis Mill. (Prévosto et al. 2012), and Pinus pinaster Ait. (Rodríguez-García et al. 2011). Lucas-Borja et al. (2011) recommend soil preparation combined with moderate or dense basal area intervals (from 25 to $40 \mathrm{~m}^{2} \mathrm{ha}^{-1}$ ) during the uniform opening of the tree canopy for Spanish black pine ( $P$. nigra Arn. ssp. salzmannii) regeneration purposes, but the authors did not address the 'nurse shrub' effect on seedling performance.

Shrub and tree covers may create favourable microsites in which environmental conditions are ameliorated to improve emergence, survival and early recruitment of conifer seedlings (Germino et al. 2002; Legras et al. 2010; Maher et al. 2005). However Rodríguez-García et al. (2011) argued that shrubs may also have a negative effect on initial seedling growth by competing for resources, but indirect facilitation can occur if the benefit of suppressing competitive species is higher than the direct negative effects (Pagès et al. 2003; Kunstler et al. 2006). Also, abiotic stress conditions may modulate this trend. Most 'nurse shrub' studies only considered the effect of shrubs on natural regeneration success in open areas, ignoring the effect of tree canopy cover on the relationship. Consequently the main objective of this study was to analyse the effects of shrub cover in combination with tree canopy cover on Spanish black pine seedling 
emergence and survival during the first growing season of two different years. We expected to find that seedling-nurse shrub interactions would vary depending on tree canopy cover, i.e. stronger and positive interactions at more stressful sites (e.g. low tree density) but negative interactions under closed tree canopy conditions resulting from a higher competition for water.

\section{Material and methods}

\subsection{Study area}

This study was led over 2 years (2012 and 2013) in Serrania de Cuenca, a mountainous area located in the region of Castilla-La-Mancha (central-eastern Spain). Spanish black pine (P. nigra Arn. ssp. salzmannii) is naturally distributed in this area between 1000 and $1500 \mathrm{~m}$ a.s.l. where it dominates forest stand composition (Del Cerro et al. 2009). Spanish black pine forests in the Cuenca Mountains have traditionally been managed using the shelterwood method, with a shelter phase of 20-25 years and a rotation period of 100-125 years (Tíscar et al. 2011). The regeneration method used, in both mixed and pure even-aged Spanish black pine stands, involves a uniform opening of the canopy without soil preparation. A dense, continuous and homogeneous mature Spanish black pine forest aged about 100-120 years old was selected in the study area at the core of the distribution range for this species (Los Palancares y Agregados, $1200 \mathrm{~m}$ a.s.1., $40^{\circ} 01^{\prime} 50^{\prime \prime} \mathrm{N} ; 1^{\circ}$ $59^{\prime} 10^{\prime \prime} \mathrm{W}$ ). The herbaceous vegetation is mainly dominated by Eryngium campestre L., Geranium sylvaticum L., Centaurea paniculata L. and Plantago media L., whereas shrub understory is composed of Juniperus oxycedrus L., Genista scorpius L., Amelanchier ovalis Medik., Acer campestre L., Corylus avellana L., Crataegus monogyna Jacq., Viburnum lantana L., Rubus sp., Rosa sp., and Prunus spinosa L. According to Allué (1990), the climate is classified as Mediterranean humid, with a mean annual temperature of $11.9{ }^{\circ} \mathrm{C}$ (mean lowest temperatures of the coldest month at $-0.5{ }^{\circ} \mathrm{C}$ and mean highest temperatures of the hottest month at $30.5{ }^{\circ} \mathrm{C}$ ) and mean annual precipitation of $595 \mathrm{~mm}$ ( $99 \mathrm{~mm}$ in summer). Calcareous soils dominate the study area, and the soil found in the experimental site is classified as leptosol according to the Soil Atlas of Europe (2005). During the last century, the forest stand was not affected by natural disturbances such as windstorms, pests and diseases, or forest fires.

\subsection{Experimental design}

A sowing experiment was conducted over 2 years (2012 and 2013) in 'Los Palancares y Agregados' forest. Based on previous knowledge on stand-structural characteristics (Lucas-
Borja et al. 2011; Candel-Pérez et al. 2012), we selected three stand basal area intervals, the basal area being used as a proxy for tree canopy cover, i.e. BA1 $\sim 15-20 \mathrm{~m}^{2} \mathrm{ha}^{-1}$, low cover; BA2 25-30 $\mathrm{m}^{2} \mathrm{ha}^{-1}$, moderate cover; and BA3 35$40 \mathrm{~m}^{2} \mathrm{ha}^{-1}$, dense cover (Table 1). Four plots were randomly distributed within each stand basal area interval at least $500 \mathrm{~m}$ apart and were thus considered independent and to form the replicates of the experiment. Each plot was occupied by the same shrub species, namely $J$. oxycedrus and G. scorpius. In spring 2012 and 2013, six subplots were established in each plot, three under the shrub cover, i.e. inside the space delimited by the vertical projection of the shrub cover, and three outside the shrub cover, i.e. at a minimum of $5 \mathrm{~m}$ away from the space delimited by the vertical projection of the shrub cover, giving a total of 72 subplots ( 3 levels of stand basal area $\times 4$ plots $\times 3$ subplots $\times 2$ shrub conditions). Each subplot was composed of $25 \times 25 \mathrm{~cm}$ quadrats with a $1-\mathrm{cm}^{2}$ mesh size and protected with a wire cage to exclude seed predation from birds and rodents. Twenty seeds collected in local Spanish black pine stands were sown $1 \mathrm{~cm}$ deep per sowing point in April 2012 and again in April 2013 (the same subplot was sown in both years). In-lab germination tests to evaluate the potential germination rates of the seeds used in 2012 and 2013 found no differences, with germination rates reaching about $85 \%$ (see Lucas-Borja et al. 2011 for details on the controlled seed germination procedure).

\subsection{Measurements}

Daily air temperature and precipitation were recorded during the entire length of the study at a meteorological station (model METEODATA 1256C) located in the same forest near the plots. Annual water budget was estimated by the standardized precipitation-evapotranspiration index (SPEI) (VicenteSerrano et al. 2010) based on the sum of monthly differences between precipitation $(\mathrm{P})$ and potential evapotranspiration (PET). Soil temperature and moisture were measured at $10-\mathrm{cm}$ depth every $20 \mathrm{~min}$ from March to September in both 2012 and 2013 using six (3 stand basal area intervals $\times 2$ shrub conditions) soil moisture and temperature sensors $\left(\mathrm{HOBO}^{\circledR} \mathrm{U} 12\right)$. Seedling emergence (early appearance of the cotyledons) and seedling survival were monitored regularly in both 2012 and 2013. Emergence and survival were surveyed every 2 weeks during late spring and monthly over the summer season.

\subsection{Statistical analysis}

The effects of stand basal area, shrub condition and year of sowing on seedling emergence and survival rates were analysed using linear mixed-effects models. Stand basal area, shrub condition and year of sowing were considered fixed effects. Experimental design was considered as nested, with 
Table 1 Forest stand structure found at each stand basal area (mean \pm standard error around the mean, SEM)

\begin{tabular}{llllll}
\hline Number of plots & $\begin{array}{l}\text { Basal area } \\
\left(\mathrm{m}^{2} \mathrm{ha}^{-1}\right)\end{array}$ & DBH (cm) & $\begin{array}{l}\text { Mean tree } \\
\text { height }(\mathrm{m})\end{array}$ & $\begin{array}{l}\text { Number of } \\
\text { trees }\left(\mathrm{N} \mathrm{ha}{ }^{-1}\right)\end{array}$ & $\begin{array}{l}\text { Shrub } \\
\text { cover (\%) }\end{array}$ \\
\hline 4 & $\begin{array}{l}\text { Dense } \\
35-40\end{array}$ & $26.0(2.1)$ & $15.1(1.1)$ & $646.4(19.1)$ & $24.1(3.8)$ \\
4 & $\begin{array}{l}\text { Medium } \\
25-30\end{array}$ & $30.0(3.3)$ & $15.0(0.9)$ & $322.1(21.1)$ & $25.9(4.3)$ \\
& Low & $32.0(3.1)$ & $14.9(0.9)$ & $183.0(18.1)$ & $27.3(4.7)$ \\
& & & & \\
\hline
\end{tabular}

the plots as the replicates nesting the subplots and the shrub condition. The plots and replicates were considered random terms in the model. Analysis of survival data was limited to the 2013 dataset, because no seedlings survived the summer of 2012. Seedling emergence and survival differences for each basal area interval and sowing position in 2012 and 2013 were evaluated according to the Tukey HSD post hoc test. All statistical analyses were performed using Statgraphics Centurion $\mathrm{XV}^{\circledR}$.

\section{Results}

\subsection{Precipitation, air and soil temperatures and soil moisture}

Mean monthly temperature presented similar values over the 2-year period studied (Fig. 1), with the exception of a warmer summer during the first year (2012). The study area receives an average annual precipitation of $784.6 \mathrm{~mm}$ (for the 19482005 period). The wettest month is December, with a mean monthly precipitation of $85.7 \mathrm{~mm}$, and the driest month is July, with a mean monthly precipitation of $21.9 \mathrm{~mm}$. The year 2012 was a drier year than 2013 (420 vs. $850 \mathrm{~mm}$ in 2012 and 2013, respectively). Precipitation showed a dramatic negative deviation from the mean values throughout most of 2012 (Fig. 2), whereas the opposite situation was recorded in 2013 where precipitation was higher-than-average in January and March and summer (from July to October). The SPEI showed a stark water deficit in the winter months of 2012 (negative values), whereas months with high water availability were observed in the year 2013 (Fig. 3).

In terms of microclimatic conditions generated by tree canopy cover and shrub cover, in general, soil temperatures were lower $\left({ }^{\circ} \mathrm{C}\right)$ outside shrub cover, both in 2012 and 2013 (Table 2). They also decreased from low to dense basal area. Soil moisture (\%) increased with increasing basal area, in particular in 2012. Finally, soil moisture values were lower outside the shrub cover. The minimum value was recorded in 2012 for subplots with low basal area and outside the shrub cover $(6.0 \%$; Table 2$)$.

\subsection{Seedling emergence}

The results of the mixed model analysis for the effects of stand basal area, shrub condition and year of sowing (2012 and 2013) showed that only year of sowing significantly influenced seedling emergence rate (chi-square ratio $=44.77$, $P<0.001$ ), associated with a significant stand basal area $\times$ year interaction (chi-square ratio $=4.16, P=0.032$ ) and a barely significant shrub cover $\times$ year interaction (chi-square ratio $=3.65, P=0.046$ ). In 2012, seedling emergence showed the best results under the moderate basal area interval (BA2 25-30 $\mathrm{m}^{2} \mathrm{ha}^{-1}$ ) and was favoured by shrub cover (emergence rate of 0.4 , Fig. 4 ), whereas seedling emergence rate was very low at both the lowest and highest basal area intervals, only exceeding $10 \%$ in plots protected by a combination of high basal area and shrub cover. In 2013, there was no significant stand basal area effect on seedling emergence nor a shrub cover effect (Fig. 4).

\subsection{Seedling survival}

In 2012, all emerged seedlings died in all shrub conditions and all basal area intervals. Consequently, only 2013 data were analysed. The results of the mixed model analysis for the effects of stand basal area and shrub condition showed that only shrub condition significantly influenced seedling survival rate (chi-square ratio $=27.72, P<0.010$ ). Neither basal area nor the interaction between stand basal area and shrub condition was significant (chi-square ratio $=2.44, P=0.095$; chi-

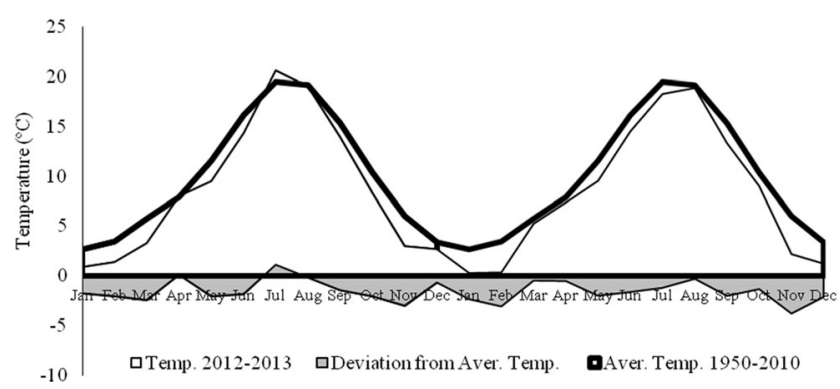

Fig. 1 Range of mean monthly temperature $\left({ }^{\circ} \mathrm{C}\right)$, normal monthly temperature (1950-2010), and deviation of mean monthly temperature from historical average temperature, for the period January 2012 to December 2013 


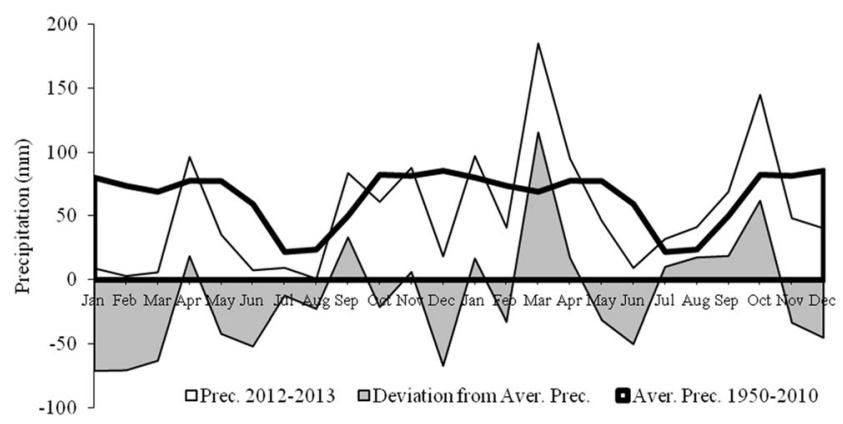

Fig. 2 Range of monthly precipitation $(\mathrm{mm})$, historical average precipitation (1950-2010) and deviation of monthly precipitation from historical average precipitation, for the period January 2012 to December 2013

square ratio $=0.11, P=0.898$, respectively). Results showed that seedling survival was higher outside shrub cover at every basal area interval (Fig. 5).

\section{Discussion}

Seedling emergence rate was strongly influenced by the considered year and the two-way interactions with shrub condition and basal area interval, likely related to the contrasted climatic features of the 2 years studied; 2012 was particularly dry and a little warmer than usual, whereas 2013 was wetter than usual. In 2012, seedling emergence was higher under the medium 25-30 $\mathrm{m}^{2} \mathrm{ha}^{-1}$ stand basal area and was favoured by being inside shrub cover, whereas in 2013, there were no significant effects of basal area or shrub condition on emergence.

Light on the forest floor is a direct consequence of canopy structure and stand/shrub density (Catovsky and Bazzaz 2000; Balandier et al. 2006b; Barbier et al. 2008); a high light level may increase soil temperature and climate demand, thus decreasing accordingly soil moisture by increasing soil evaporation, as recorded in this particularly difficult conditions under the lowest tree canopy cover (Table 2). Soil temperature and

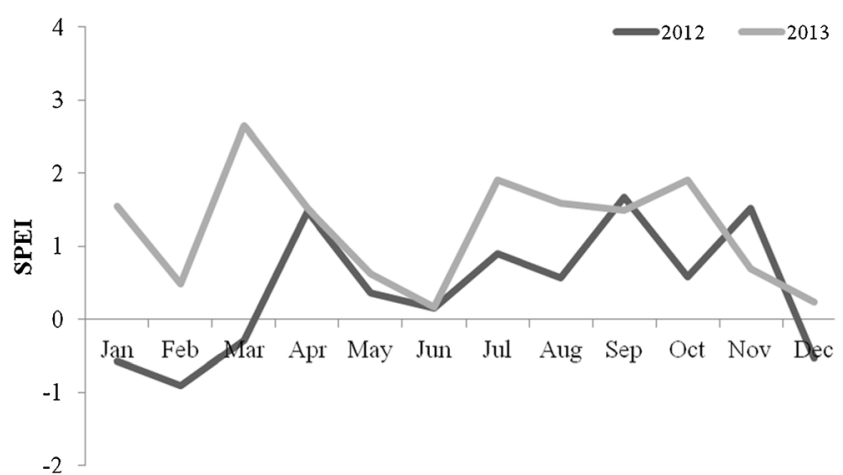

Fig. 3 Standardized Precipitation-Evapotranspiration Index (SPEI) for 2012 and 2013, estimated from a standardized sum of monthly differences between precipitation $(\mathrm{P})$ and potential evapotranspiration (PET) humidity are likely to be the two main drivers of germination and seedling emergence under field conditions (Lee et al. 2004; Castro et al. 2005; Del Cerro et al. 2009). There is broad evidence (Holmgren et al. 1997; Del Cerro et al. 2009) that soil and air temperatures are lower under tree canopy, wind velocity is reduced and air humidity is higher than in open areas, thus reducing seedling transpiration demand and soil evaporation. Furthermore, field experiments conducted on the forest floor under pine stands indicated that germination is soil-water content-dependent (Lee et al. 2004).

In the Cuenca mountains conditions, the micrometeorological and light conditions found under moderate basal area interval and inside shrub cover conditions would have generated a better environment for Spanish black pine seedling emergence in the drier and warmer year 2012 (Granda et al. 2012). On one hand, higher basal area was unfavourable, probably because the competition for light, or other resources, or through allelopathic processes sometimes mentioned, is too high. Higher light conditions (low tree canopy cover and outside shrub cover) are less favourable as they do not generate adequate conditions for emergence in drier and warmer years. Therefore, it seems that for the conditions of the Cuenca Mountains, the considered shrub species (J. oxycedrus and G. scorpius), and the considered dryness in 2012, interactions between pine seedlings, shrubs and adult trees moved from competition at high and low stand basal area to facilitation at moderate basal area. The positive effect of shrub cover on seedling emergence may have been driven by increased moisture resulting from the effects of shrub cover on soil temperature and relative air humidity (Holmgren et al. 1997). These results support the Bertness and Callaway (1994) theoretical model predicting a switch from competition to facilitation with increasing harshness of the environment and also the 'collapse of facilitation' model (Michalet et al. 2006) for the harshest sites. Further evidence that facilitation collapses under extreme stress levels was the zero survival in 2012 both with and without shrub cover protection, as also found by Kitzberger et al. (2000). However, as our results came from only 2 years and a single forest, they obviously need to be replicated in other places and years to be generalized.

In contrast, neither basal area nor shrub condition had significant effects on seedling emergence under the more favourable climate conditions and higher soil moisture recorded in 2013. Drought alleviation and higher water availability during 2013 allowed Spanish black pine to emerge without shrub and canopy cover protection (Castro et al. 2005).

Seedling survival rate was null in the drier and warmer year (2012). As different authors argued, seedling survival is one of the most critical stages in a plant's life history, and is often reduced by drought and high temperatures in the Mediterranean basin (Madrigal et al. 2004; Padilla and Pugnaire 2007), where water deficit in the summer appears to be the dominant cause of seedling mortality (Valladares 2004). 
Table 2 Soil temperature and moisture (mean \pm standard error around the mean, SEM) measured at $10 \mathrm{~cm}$ depth from March to September in 2012 and 2013 tabulated by stand basal area interval and shrub conditions

\begin{tabular}{|c|c|c|c|c|c|c|c|c|}
\hline \multirow[t]{3}{*}{ Stand basal area interval ${ }^{\mathrm{a}}$} & \multicolumn{4}{|l|}{2012} & \multicolumn{4}{|l|}{2013} \\
\hline & \multicolumn{2}{|c|}{ Soil temperature $\left({ }^{\circ} \mathrm{C}\right)$} & \multicolumn{2}{|c|}{ Soil moisture (\%) } & \multicolumn{2}{|c|}{ Soil temperature $\left({ }^{\circ} \mathrm{C}\right)$} & \multicolumn{2}{|c|}{ Soil moisture (\%) } \\
\hline & ISC & OSC & ISC & OSC & ISC & OSC & ISC & OSC \\
\hline Dense & $7.1(0.5)$ & $7.3(0.4)$ & $12.1(0.4)$ & $10.9(0.3)$ & $5.0(0.5)$ & $6.2(0.3)$ & $12.3(0.5)$ & $11.3(0.4)$ \\
\hline Medium & $8.2(0.4)$ & $10.0(0.3)$ & $11.0(0.3)$ & $6.2(0.2)$ & $6.1(0.5)$ & $8.1(0.2)$ & $12.2(0.3)$ & $8.7(0.3)$ \\
\hline Low & $8.0(0.3)$ & $10.5(0.3)$ & $10.0(0.2)$ & $6.0(0.5)$ & $7.9(0.4)$ & $8.5(0.4)$ & $12.1(0.4)$ & $8.5(0.5)$ \\
\hline
\end{tabular}

ISC inside shrub cover, OSC outside shrub cover)

${ }^{\mathrm{a}}$ Basal area intervals (low (BA1 15-20 $\mathrm{m}^{2} \mathrm{ha}^{-1}$ ), medium (BA2 25-30 $\mathrm{m}^{2} \mathrm{ha}^{-1}$ ) and dense (BA3 35-40 $\mathrm{m}^{2} \mathrm{ha}^{-1}$ ))

Drought pressure is the most important factor controlling regeneration density of $P$. nigra ssp. pallasiana (Fyllas et al. 2008), especially in the first growing season (Del Cerro et al. 2009). Note that the more favourable climatic conditions in 2013 allowed seedlings to survive until the end of the experiment. We observed that survival was better achieved outside shrub cover under the more favourable conditions of 2013 without basal area influence. This fact suggests a light effect
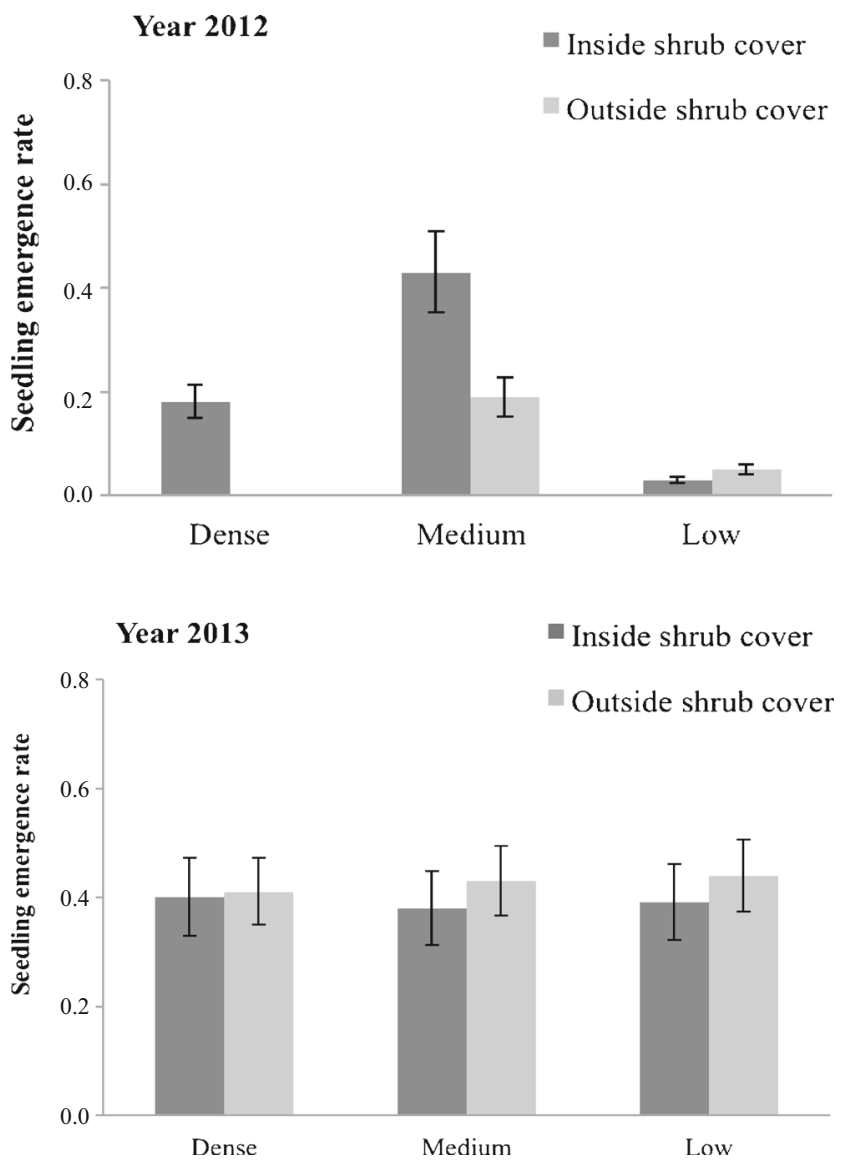

Fig. 4 Seedling emergence rate at different sowing positions (inside or outside shrub cover) and different basal area intervals (low (BA1 15$20 \mathrm{~m}^{2} \mathrm{ha}^{-1}$ ), medium (BA2 25-30 $\mathrm{m}^{2} \mathrm{ha}^{-1}$ ) and dense (BA3 35$\left.40 \mathrm{~m}^{2} \mathrm{ha}^{-1}\right)$ ) in 2012 and 2013. Error bars are the Tukey HSD at $P<0.05$ (seedlings receive higher light outside shrub cover), as already reported by Adili et al. (2013) and also a shrub competition effect with decreasing harshness (Bertness and Callaway 1994) without adult trees influence.

In fact, seedling establishment and early growth may be prevented by successive filters, including variability in seed production, light and understory vegetation. Water availability is thus the primary limiting factor, but when it becomes nonlimiting in case of favourable climate conditions (2013), then light becomes the next biggest limiting factor. Indeed, solar radiation appears to be an important environmental factor defining the regeneration niche of pine species: higher solar radiation implies higher seedling survival and higher initial seedling growth (Rodríguez-García et al. 2011). Simard et al. (1998) stated that increased light favours a longer taproot and longer shoots in seedlings, enabling them to penetrate the soil and survive better. When seedling roots extend deeper into soil, they uptake sufficient water to increase the chances of seedling survival. Here, the absence of soil water deficit during 2013, as demonstrated in the calculated SPEI, may have helped the Spanish black pine seedlings to survive until the arrival of autumn rains. Finally, basal area was a not significant factor in relation to seedling survival in 2013,

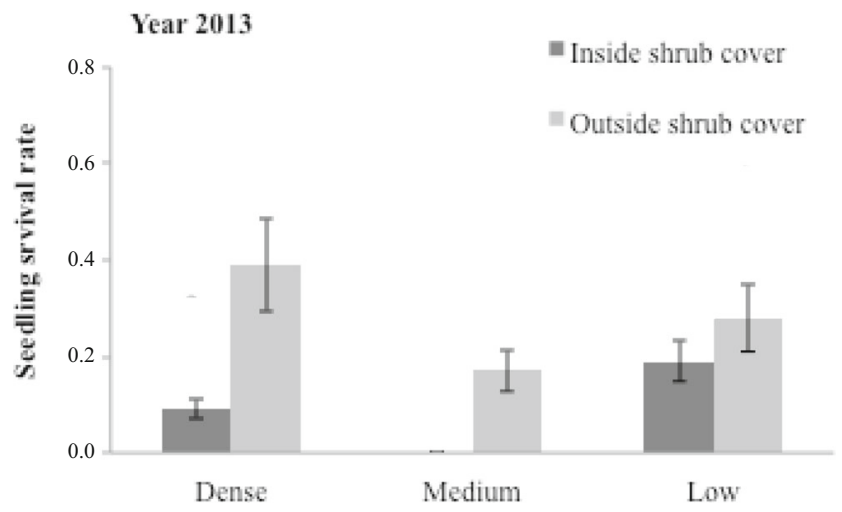

Fig. 5 Seedling survival rate at different sowing positions (inside or outside shrub cover) and different basal area intervals (low (BA1 $\sim 15$ $20 \mathrm{~m}^{2} \mathrm{ha}^{-1}$ ), medium (BA2 25-30 $\mathrm{m}^{2} \mathrm{ha}^{-1}$ ) and dense (BA3 35$\left.40 \mathrm{~m}^{2} \mathrm{ha}^{-1}\right)$ ) in 2013. Error bars are the Tukey HSD at $P<0.05$ 
suggesting that the strength of tree-seedling interactions is significantly lower in wet years (Gómez-Aparicio et al. 2004).

\section{Conclusion}

As shown by Lucas-Borja et al. (2012), the natural regeneration of Spanish black pine has to go through conflicting situations between conditions suitable for seedling emergence (medium basal area interval and inside shrub cover) and conditions suitable for seedling survival (outside shrub cover without basal area influence), this effect being modulated by climate of the given year. Shrub facilitation was only confirmed for seedling emergence in the drier year under moderate light (medium basal area), whereas shrub cover does not promote seedling survival and basal area is not an influential factor in the wetter year. Indeed the findings reported here point to bleak prospects for natural Spanish black pine regeneration success in the driest years like 2012, with no survival at the end of the growing season, whatever the basal area or shrub cover conditions. In addition we have to highlight that the climate conditions of 2012 could become more frequent with the ongoing climate changes. Therefore, forest managers should indeed take advantage of the wettest years to promote black pine regeneration by clearing shrubs after seedling emergence to increase light availability and avoid shrub competition.

Acknowledgments The authors thank INIA funds (National Research project GEPRIF (RTA2014-00011-C06-05)). Consejería de Agricultura (JCCM) provided the necessary support to carry out the fieldwork in Cuenca Mountains. The authors thank the Cuenca Mountain Forest Service for site access and Julian Molero Carrasco for field assistance. David Candel-Pérez would like to thank the European Social Fund and the JCCM, under the ESF Operational Programme 2007-2013, for his FPU Grant, and also to CYTEMA-UCLM for the fellowship to stay at a foreign research centre (IRSTEA, France).

\section{Compliance with ethical standards}

Funding This work was supported by Junta de Comunidades de Castilla-La Mancha (JCCM) [POII10-0112-7316] and INIA funds (National Research project GEPRIF (RTA2014-00011-C06-05)). David Candel-Pérez would like to thank the European Social Fund and the JCCM, under the ESF Operational Programme 2007-2013, for his FPU Grant.

\section{References}

Adili B, El Aouni MH, Garchi S, Balandier P (2009). Natural regeneration of Pinus pinea $\mathrm{L}$. in Tunisia as influenced by canopy cover, litter biomass and understorey vegetation. In: Final COST E47 conference. Forest vegetation management towards environmental sustainability. Vejle, Denmark. University of Copenhagen, Forest and Landscape Denmark, pp 66-68
Adili B, El Aouni MH, Balandier P (2013) Unraveling the influence of light, litter and understory vegetation on Pinus pinea natural regeneration. Forestry 86:297-304

Agestam E, Ekö PM, Nilsson U, Welander NT (2003) The effects of shelterwood density and site preparation on natural regeneration of Fagus sylvatica in southern Sweden. For Ecol Manag 176:61-73

Allué JL (1990) Atlas fitoclimático de España. Taxonomías. Ministerio de Agricultura, Pesca y Alimentación, Instituto Nacional de Investigaciones Agrarias, Madrid

Balandier P, Collet C, Miller JH, Reynolds PE, Zedacker SM (2006a) Designing forest vegetation management strategies based on the mechanisms and dynamics of crop tree competition by neighbouring vegetation. Forestry 79:3-27

Balandier P, Sonohat G, Sinoquet H, Varlet-Grancher C, Dumas Y (2006b) Characterisation, prediction and relationships between different wavebands of solar radiation transmitted in the understorey of even-aged oak (Quercus petraea, Q. robur) stands. Trees 20:363370

Barbeito I, Fortin MJ, Montes F, Cañellas I (2009) Response of pine natural regeneration to small-scale variation on a managed Mediterranean mountain forest. Appl Veg Sci 12:488-503

Barbier S, Gosselin F, Balandier P (2008) Influence of tree species on understory vegetation diversity and mechanisms involved-a critical review for temperate and boreal forests. For Ecol Manag 254:115

Bertness MD, Callaway R (1994) The role of positive forces in natural communities. Trends Ecol Evol 9:191-193

Callaway RM (1995) Positive interactions among plants. Bot Rev 61: 306-349

Callaway RM, Walker LR (1997) Competition and facilitation: a synthetic approach to interactions in plant communities. Ecology 78:19581965

Callaway RM, Brooker RW, Choler P, Kikvidze Z, Lortie CJ, Michalet R et al (2002) Positive interactions among alpine plants increase with stress. Nature 417:844-848

Candel-Pérez D, Linares JC, Viñegla B, Lucas-Borja ME (2012) Assessing climate-growth relationships under contrasting stands of co-occurring Iberian pines along an altitudinal gradient. For Ecol Manag 274:48-57

Castro J, Zamora R, Hódar JA, Gómez JM (2005) Ecology of seed germination of Pinus sylvestris L. at its southern, Mediterranean distribution range. Investig Agrar: Sist Recur For 14:143-152

Catovsky S, Bazzaz FA (2000) The role of resource interactions and seedling regeneration in maintaining a positive feedback in hemlock stands. J Ecol 88:100-112

Del Cerro Barja A, Lucas Borja ME, Martínez García E, Navarro López R, Andrés Abellán M, López Serrano FA (2009) The influence of stand density and soil treatment on the Spanish black pine (Pinus nigra Arn. ssp. salzmannii) regeneration in Spain. Investig Agrar: Sist Recur For 18:167-180

Emborg J (1998) Understorey light conditions and regeneration with respect to the structural dynamics of a near-natural temperate deciduous forest in Denmark. For Ecol Manag 106:83-95

Fyllas NM, Dimitrakopoulos PG, Troumbis AY (2008) Regeneration dynamics of a mixed Mediterranean pine forest in the absence of fire. For Ecol Manag 256:1552-1559

Germino MJ, Smith WK, Resor C (2002) Conifer seedling distribution and survival in an alpine-treeline ecotone. Plant Ecol 162:157-168

Gómez-Aparicio L, Zamora R, Gómez JM, Hódar JA, Castro J, Baraza E (2004) Applying plant facilitation to forest restoration in Mediterranean ecosystems: a meta-analysis of the use of shrubs as nurse plants. Ecol Appl 14:1128-1138

Gómez-Aparicio L, Valladares F, Zamora R, Quero JL (2005) Response of tree seedlings to the abiotic heterogeneity generated by nurse shrubs: an experimental approach at different scales. Ecography 28:757-768 
Granda E, Escudero A, De La Cruz M, Valladares F (2012) Juvenile-adult tree associations in a continental Mediterranean ecosystem: no evidence for sustained and general facilitation at increased aridity. J Veg Sci 2:164-175

Holmgren M, Scheffer M, Huston MA (1997) The interplay of facilitation and competition in plant communities. Ecology 78:1966-1975

Howard KSC, Eldridge DJ, Soliveres S (2012) Positive effects of shrubs on plant species diversity do not change along a gradient in grazing pressure in an arid shrubland. Basic Appl Ecol 13:159-168

Kerr G (2000) Natural regeneration of Corsican pine (Pinus nigra subsp. laricio) in Great Britain. Forestry 73:479-488

Kerr G (2008) Managing continuous cover forests. Forestry commission operational guidance booklet 7. Forestry Commission, Edinburgh

Kitzberger T, Steinaker DF, Veblen TT (2000) Effects of climatic variability on facilitation of tree establishment in Northern Patagonia. Ecology 81:1914-1924

Kunstler G, Curt T, Bouchaud M, Lepart J (2006) Indirect facilitation and competition in tree species colonization of sub-Mediterranean grasslands. J Veg Sci 17:379-388

Le Bagousse-Pinguet Y, Maalouf JP, Touzard B, Michalet R (2014) Importance, but not intensity of plant interactions relates to species diversity under the interplay of stress and disturbance. Oikos 123: 777-785

Lee CS, Kim JH, Yi H, You YH (2004) Seedling establishment and regeneration of Korean red pine (Pinus densiflora S. et Z.) forests in Korea in relation to soil moisture. For Ecol Manag 199:423-432

Legras EC, Vander Wall SB, Board DI (2010) The role of germination microsite in the establishment of sugar pine and Jeffrey pine seedlings. For Ecol Manag 260:806-813

López-Serrano FR, Rubio Caballero E, Andrés Abellán M, Del Cerro Barja A, García Morote FA, De las Heras Ibañez J, Lucas-Borja ME, Moya Navarro D, Odi Lara M (2009) Efectos del Cambio climático en los bosques castellano-manchegos. In: Rodríguez Torres A, Fernández Castro H, Rojano Saura I (eds) Impactos del Cambio climático en Castilla La Mancha. Fundación General de Medio Ambiente, Castilla-La Mancha, Spain

Lucas-Borja ME, Silva-Santos P, Fonseca T, Tíscar PA, López Serrano FR, Andrés Abellán M, Martínez García E, Del Cerro Barja A (2010) Modelling Spanish black pine postdispersal seed predation in Central-eastern Spain. Forest Syst 19:393-403

Lucas-Borja ME, Fonseca T, Parresol B, Silva-Santos P, García-Morote FA, Tíscar PA (2011) Modelling Spanish black pine seedling emergence: establishing management strategies for endangered forest areas. For Ecol Manag 262:195-202

Lucas-Borja ME, Fonseca Fidalgo T, Linares JC, García-Morote FA, López-Serrano FR (2012) Does the recruitment pattern of Spanish black pine (Pinus nigra Arn ssp. salzmannii) change the regeneration niche over the early life cycle of individuals? For Ecol Manag 284:93-99

Madrigal J, Martínez E, Hernando C, Guijarro M, Díez C, Vega JA, Pérez-Gorostiaga P, Fonturbel MT, Cuiñas P, Alonso M, Beloso MC (2004) Respuesta a corto plazo del regenerado post-incendio de Pinus pinaster Ait. Aclareos mecanizados intensos. Silva Lusitana 12:1-14

Maestre FT, Cortina J (2004) Are Pinus halepensis plantations useful as a restoration tool in semiarid Mediterranean areas? For Ecol Manag 198:303-317
Maestre FT, Valladares F, Reynolds JF (2005) Is the change of plant-plant interactions with abiotic stress predictable? A meta-analysis of field results in arid environments. J Ecol 93:748-757

Maher EL, Germino MJ, Hasselquist NJ (2005) Interactive effects of tree and herb cover on survivorship, physiology, and microclimate of conifer seedlings at the alpine tree-line ecotone. Can J For Res 35: 567-574

Michalet R, Brooker RW, Cavieres LA, Kikvidze Z, Lortie CJ, Pugnaire FI, Valiente-Banuet A, Callaway RM (2006) Do biotic interactions shape both sides of the humped-back model of species richness in plant communities? Ecol Lett 9:767-773

Michalet R, Le Bagousse-Pinguet Y, Maalouf JP, Lortie CJ (2014) Two alternatives to the stress-gradient hypothesis at the edge of life: the collapse of facilitation and the switch from facilitation to competition. J Veg Sci 25:609-613

Padilla FM, Pugnaire FI (2007) Rooting depth and soil moisture control Mediterranean woody seedling survival during drought. Funct Ecol 21:449-489

Page LM, Cameron AD, Clarke GC (2001) Influence of overstorey basal area on density and growth of advance regeneration of Sitka spruce in variably thinned stands. For Ecol Manag 151:25-35

Pagès JP, Pache G, Joud D, Magnan N, Michalet R (2003) Direct and indirect effects of shade on four forest tree seedlings in the French Alps. Ecology 84:2741-2750

Prévosto B, Amandier L, Quesney T, De Boisgelin G, Ripert C (2012) Regenerating mature Aleppo pine stands in fire-free conditions: site preparation treatments matter. For Ecol Manag 282:70-77

Rodríguez-García E, Ordóñez C, Bravo F (2011) Effects of shrub and canopy cover on the relative growth rate of Pinus pinaster Ait. seedlings of different sizes. Ann For Sci 68:337-346

Simard MJ, Bergeron Y, Sirois L (1998) Conifer seedling recruitment in a southeastern Canadian boreal forest: the importance of substrate. J Veg Sci 9:575-582

Soil Atlas of Europe (2005) European soil bureau network. European Commission, Luxembourg

Sthultz CM, Gehring CA, Whitham TG (2007) Shifts from competition to facilitation between a foundation tree and a pioneer shrub across spatial and temporal scales in a semiarid woodland. New Phytol 173:135-145. doi:10.1111/j.1469-8137.2006.01915.x

Tíscar PA (2007) Dinámica de regeneración de Pinus nigra subsp. salzmannii al sur de su área de distribución: etapas, procesos y factores implicados. Investig Agrar: Sist Recur For 16:124-135

Tíscar PA, Linares JC (2014) Large-scale regeneration patterns of Pinus nigra Subsp. salzmannii: poor evidence of increasing facilitation across a drought gradient. Forests 5:1-20. doi:10.3390/f5010001

Tíscar PA, Lucas-Borja ME, Candel Pérez D (2011) Changes in the structure and composition of two Pinus nigra subsp. salzmannii forests over a century of different silvicultural treatments. Forest Syst 20: $525-535$

Valladares F (2004) Ecología del bosque mediterráneo en un mundo cambiante. Ministerio de Medio Ambiente. EGRAF, Madrid

Vicente-Serrano SM, Beguería S, López-Moreno JI (2010) A multiscalar drought index sensitive to global warming: the Standardized Precipitation Evapotranspiration Index. J Clim 23:1696-1718 